\title{
The Effect Of Repeat Training Methods On Increasing Passing Results Parts In Football
}

\author{
Alchonity Harika Fitri ${ }^{1)}$, Ambiyar ${ }^{2 *}$, Ishak Aziz ${ }^{3)}$ \\ 1) Program Studi Doktor Ilmu Pendidikan Pascasarjana Universitas Negeri Padang \\ 2,3) Universitas Negeri Padang \\ *Coresponding Author \\ Email : alchonityhfa@gmail.com
}

\begin{abstract}
This study aims to identify and understand the effect of repeat training methods on increasing passing results parts in football. The type of research is experimental, with the design of this study using a quasi experiment with a one group pretest-posttest design. The population was the students of SMA Unggul Dharmasraya West Sumatra. Data collection was done by conducting pre-test and post-test passing accuracy of the students. Based on the results of calculations that have been carried out, a significant value of 2.01 1,000 is obtained. Thus, the hypothesis states that there is a significant difference in the effect of repetition training on improving the inner foot passing of football of SMA Unggul Dharmasraya West Sumatra, which is acceptable.
\end{abstract}

Keywords: Repeat training methods, increasing passing, football

\section{INTRODUCTION}

Education is an obligation that must be carried out by every citizen. Education should also be carried out as early as possible in order to improve the quality of life. The existence of physical education, sports, and health in schools is very much needed, not only to improve children's physical fitness, but also to provide varied and beneficial movement experiences for students. Not only that, sport contains elements of values that are important in life. Football is one of the most popular sports among people society because the game of football is often done by children, adults or parents. Football is a team game, each team consists of eleven players, and one of them is a goalkeeper. This game is played almost entirely with the legs, except for the goalkeeper who is allowed to use his arms in the penalty kick area. The smooth and controlled movement of the player expresses his individuality in team play. Speed, strength, stamina, skill and knowledge of tactics are all important aspects of performance. Various challenges faced by players may be the main attraction of this game (Amri, 2016).

The creation of a good football game requires basic technical training. There are many basic technical movements in football, namely kicking, controlling, heading, dribbling, throwing, guarding, and grabbing. Without these basic techniques, the game of football will not live (Amri, 2016). To be able to produce an optimal soccer game, a player must be able to master the techniques in the game of football. The basic technique of playing football is the ability to make movements or do something that cannot be separated from the game of football (Witiyasari, 2014). The earliest movement in playing football is passing. A player must master 
the basic skills of kicking a ball and then develop various techniques in soccer. To be good at playing ball, that is by learning basic techniques, one of which is learning to pass in soccer games. Passing is the art of transferring the momentum of the ball from one player to another. The way to pass in soccer is to swing the leg that will kick back then put on the inside of the foot at the same time hitting the ball with the hip axis (Witiyasari, 2014).

Based on the results of the initial observations that the researchers did at SMA Unggul Dharmasraya West Sumatra, it showed that, out of 15 students, 3 students (30\%) had been able to do soccer passing techniques properly and correctly and the remaining 8 students $(70 \%)$ still had not mastered the movement well and Correct. Another problem faced by students of SMA Unggul Dharmasraya West Sumatra when passing is that the fulcrum is not parallel to the target direction or the tip of the foot is towards the target, the part of the student's foot that hits the ball is not the inside but the sole of the foot, and the impact on the ball is not in the middle of the back. the ball but on the ball, the body position is not balanced when kicking.

Based on the description of the background above, the author is interested in conducting a study entitled the effect of repeat training methods on increasing passing results part in football. In accordance with the statement, the implementation of passing will tend to appear with ball control ready for further action. So the reaction speed of the control ready to use will support the speed of a game that is coupled with the flow of passing ball.

\section{RESEARCH METHODS}

David Goldlatt and Johnny Acton stated in his book that "No matter how perfectly a pass is delivered, it will be wasted if the receiver fails to control the ball effectively" (Goldlat, D \& Acton, J, 2018: 118), this has it means that in any form the bait will be in vain if the recipient fails to control the ball effectively or controls the ball ready for further action. By experiencing these situations during practice, players are able to improve technical, tactical and physiological aspects of their games "(Owen et al., 2004: 50). By experiencing this situation during training, players can improve their technical, tactical and physiological aspects of the game. Abichandani and Hule (2017) argue that "Football is a sport requiring a great number of technical skills as well as static, semi-dynamic and dynamic balance". The point is that football is a sport that requires static and dynamic technical skills. This means that in football games an athlete is required to have the skills and physical abilities and balance in order to play perfectly. According to Saputro, Hariyoko, and Amiq (2016) football is played on grass with two wickets, on two sides wide guarded each by a goalkeeper. Both teams other than the goalkeeper, fighting each other to the ball to put into the opponent's goal. Soccer is a highly demanding game in which the participants are subjected to numerous actions that require overall strength and power production, speed, agility, balance, stability, flexibility, and the adequate level of endurance (Jovanovic, Sporis, Omrcen, and Fiorentini, 2011) To play Football well, each player must master some basic techniques in playing Soccer, such as herding, feeding, controlling the ball (stopping), shooting, heading, grabbing the ball and goalkeeping techniques (Yasriuddin, 2012). Football is more than just sports, but rather became a show favored by all walks of life (Kommarudin, 2005). Players who are skilled in the game, especially Soccer, will continue to survive until the end of the game and can have a lot of trust in the team, while players who are slow or weak in soccer will rarely get feedback from teammates (Nururi, and Sulaiman, 2015). 
In football games, passing is a very important part of some basic football techniques. According to Mielke (2007: 19) "passing is the art of moving a ball from one player to another. According to Danny Mielke (2007: 20), good passing begins when a team that is in possession of the ball creates space between opponents by moving and opening space around the player. Not being able to pass the ball means that you can't play ball. On the other hand, according to Djezed and Dervish in Prengky (2011: 9) "passing is an attempt to move the ball from one place to another using feet or parts of the foot". So, the accuracy of passing is the ability of a player to pass the ball with the direction of the target in accordance with the desired without deviating and optimal. In order to get the accuracy of the ball to a friend when the ball is silent or the ball is (passing accuracy), it is necessary to do an exercise with the correct method of training.

\section{RESULTS AND DISCUSSION}

\section{Hypothesis}

The hypothesis according to Suharsimi Arikunto (2012) is a temporary answer to the research problem, until it is proven through the collected data. Based on the theoretical study that has been formulated in accordance with the problem, the hypotheses in this study can be formulated as follows:

1. Ha : There is an effect of the repetition method of passing practice on improving football passing results of the students at SMA Unggul Dharmasraya West Sumatra.

2. HO : There is no effect of the method of passing repetition training on the improvement of football passing results of the students at SMA Unggul Dharmasraya West Sumatra.

\section{Type of Research}

This type of research is experimental, with the design of this study using a quasi experiment with a one group pretest-posttest design. This design also does not have a comparison group (control), the design is carried out by observing 2 times, namely before and after the action (Notoadmojo, 2010). The form of this design is as follows:

$$
\text { Pretest Treatment Posttest }
$$

Information :

01 : The pretest score of the football passing (before using the repeating exercise mote)

$\mathrm{X} \quad$ : The use of the soccer passing repetition training method

02 : Posttest scores of football passing results (after using the passing repetition training method)

$02-01$ : The difference in the results of football passing before and after using the soccer passing repetition training method

\section{Data Description}

The description of the data in this study is intended to provide an overview of the sample or variable under study. The research results and their interpretation are presented. The presentation of the results of the study is based on statistical analysis carried out on the initial test and the final test of the repetition of the repetition of the improvement of the results of the 
inner foot passing of football. The following is a description of the data, analysis of requirements testing, hypothesis testing and discussion of research results.

Results of Passing the Inner Legs in the Pre-Test and Post-Test of Students

\begin{tabular}{llcc}
\hline No & $\begin{array}{c}\text { Student } \\
\text { Code }\end{array}$ & Pree-test & Post-test \\
\hline 1. & FR & 3 & 4 \\
2. & MAH & 3 & 5 \\
3. & RR & 4 & 5 \\
4. & HA & 2 & 4 \\
5. & IH & 3 & 5 \\
6. & DB & 5 & 5 \\
7. & KF & 4 & 5 \\
8. & TF & 3 & 4 \\
9. & MP & 4 & 5 \\
10. & AW & 4 & 5 \\
11. & MD & 4 & 3 \\
12. & MF & 5 & 4 \\
13. & MFPR & 2 & 3 \\
14. & RMD & 3 & 3 \\
15. & MF & 2 & 3 \\
\hline
\end{tabular}

From the table above, it can be seen that the passing ability of the students of SMA Unggul Dharmasraya West Sumatra, has a good improvement after the repetition model exercise is carried out to improve the inner foot passing of football.
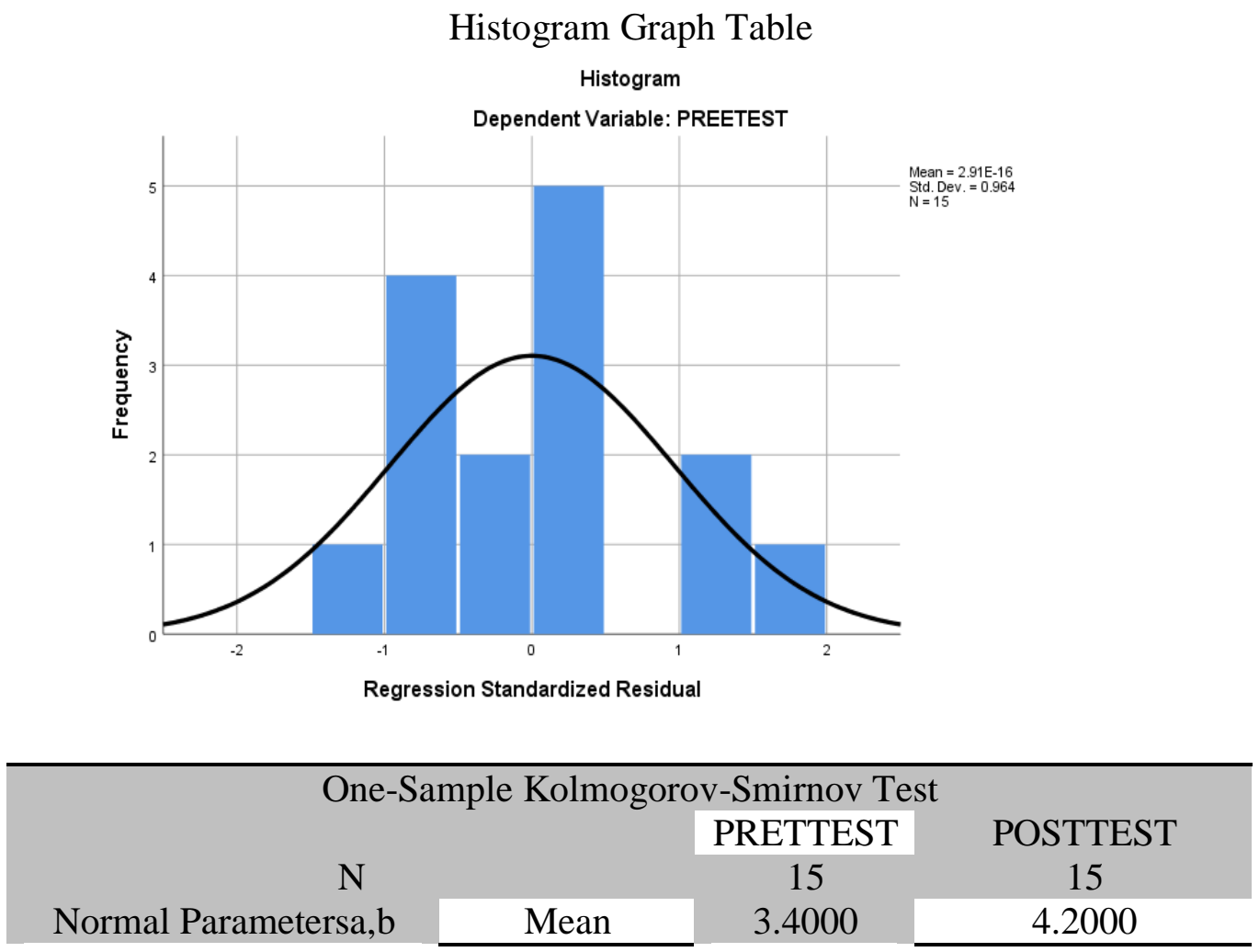


\begin{tabular}{c|ccc}
\hline & Std. Deviation & .98561 & .86189 \\
Most Extreme & Absolute & .195 & .290 \\
Differences & Positive & .191 & .185 \\
& Negative & -.195 & -.290 \\
Test Statistic & .195 & .290 \\
Asymp. Sig. (2-tailed) & $.128 \mathrm{c}$ & $.001 \mathrm{c}$ \\
& a. Test distribution is Normal. \\
& b. Calculated from data. \\
c. Lilliefors Significance Correction. \\
\hline
\end{tabular}

From the table above. The sig of all variables is greater than 0.05 , so the hypothesis that the sample is based on a normally distributed population is accepted. From this information, the variable data in this study can be analyzed using a parametric statistical approach.

The number of samples used in this study amounted to 15 people. The purpose of this study was to see the effect of the repetition training method on improving the results of inner foot passing in football at the extracurricular activities of SMA Unggul Dharmasraya West Sumatra. The discussion of the results of this study provides further interpretation of the results of the data analysis that have been presented. Based on the hypothesis testing has resulted in two groups of analytical conclusions, namely:

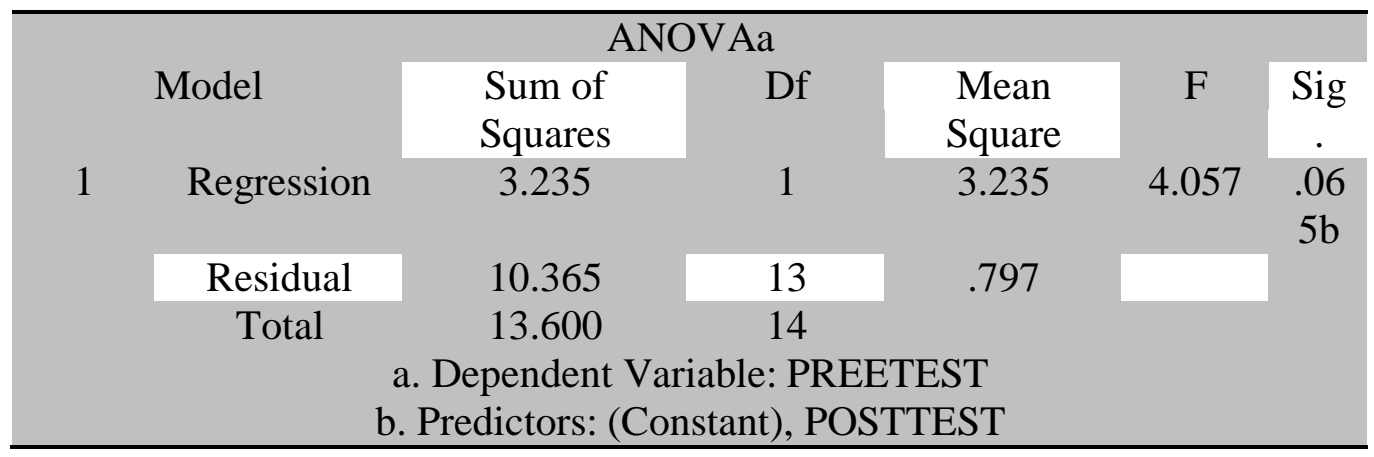

Based on the table above, it can be seen that the significant value is $0.65>0.05$, so it can be concluded that the results of the hypothesis can be accepted. There is a significant difference in influence between the main research factors. The main factors studied include: the type of method of repetition of the passing practice and the improvement of the inner foot passing

\begin{tabular}{|c|c|c|c|c|c|c|c|c|}
\hline & \multirow{3}{*}{ Model } & & & \multirow{3}{*}{$\begin{array}{c}\text { Coefficientsa } \\
\text { Standardized } \\
\text { Coefficients } \\
\text { Beta }\end{array}$} & \multirow{3}{*}{$\mathrm{t}$} & \multirow{3}{*}{ Sig } & \multirow{2}{*}{\multicolumn{2}{|c|}{$\begin{array}{l}\text { Collinearity } \\
\text { Statistics }\end{array}$}} \\
\hline & & \multicolumn{2}{|c|}{$\begin{array}{l}\text { Unstandardized } \\
\text { Coefficients }\end{array}$} & & & & & \\
\hline & & B & Std. Error & & & & $\begin{array}{l}\text { Toleran } \\
\text { ce }\end{array}$ & VIF \\
\hline 1 & $\begin{array}{c}\text { (Constan } \\
\text { t) }\end{array}$ & 2.750 & .748 & & $\begin{array}{c}3.67 \\
8\end{array}$ & $\begin{array}{c}.00 \\
3\end{array}$ & & \\
\hline & $\begin{array}{c}\text { PREETE } \\
\text { ST }\end{array}$ & .426 & .212 & .488 & $\begin{array}{c}2.01 \\
4\end{array}$ & $\begin{array}{c}.06 \\
5\end{array}$ & 1.000 & 1.000 \\
\hline
\end{tabular}


Based on the test of the first hypothesis, it shows a significant effect between the effect of repetition training on increasing the results of foot passing in the extracurricular football section of male students of SMA Unggul Dharmasraya West Sumatra. Based on the results of calculations that have been carried out, a significant value of 2.01 1,000 is obtained. Thus, the hypothesis states that there is a significant difference in the effect of repetition training on improving the inner foot passing of football of SMA Unggul Dharmasraya West Sumatra, which is acceptable.

\section{CONCLUSION}

Based on the results of the research and the results of data analysis that has been carried out, the following conclusions can be obtained: There is a significant difference in the effect of repetition training methods on improving the results of inner leg passing in football. the results of calculations that have been carried out, a significant value of 2.01 1,000 is obtained. Thus, the hypothesis states that there is a significant difference in the effect of repetition training on improving the inner foot passing of football of SMA Unggul Dharmasraya West Sumatra, which is acceptable.

\section{REFERENCES}

Abichandani Deepa \& Vinayak Hule, 2017. Assessment of Anaerobic Power and Balance among Elite Indian Under-19 Football Players. International Journal of Science and Research (IJSR) vol 6 issue 9.

Jovanovic, M., Sporis, G., Omrcen, D., Fiorentini, F. (2011). Effects of speed, agility, quickness training method on power performance in elite soccer players. Journal of Strength and Conditioning Research, 25(5), 1285-1292.

Nururi, A. N., \& Sulaiman. (2015). Permainan sepak bola (dora) dalam pembelajaran penjasorkes kelas vi sd negeri palebon $02 \mathrm{kec}$. Pedurungan kota semarang tahun 2013. ACTIVE: Journal of Physical Education, Sport, Health and Recreation, 4(7).

Mielke, Danny. (2007). Football Basics. Bandung: Raya Expert.

Muhajir. 2007. Physical and Physical Education. Bandung: Yudistira.

Owen, Adam; Twist, Craig; Ford, P. (2004). Small-Sided Games: the Physiological and Technical Effect of Altering Pitch Size and Player Numbers. Insight, 7(2), 50-53.

Prengky. (2011) "analysis of Basic Passing and Control Techniques of PS Rajawali Regency of South Bengkulu Players" (thesis). Padang: FIK UNP Padang

Saputro, A. B., Hariyoko, \& Amiq, F. (2016). Pengaruh latihan running with the ballterhadap peningkatan kecepatan lari pemain persatuan sepakbola djagung kota malang. Jurnal Pendidikan Jasmani, 26(1), 1-16.

Yasriuddin. (2012). Survey keterampilan bermain sepakbola siswa sma negeri 3 sungguminasa kabupaten gowa. Jurnal ILARA, 3(2), 63-71 